\title{
MULTIDISSIPLINÊRE BESKOUINGE OP VEROUDERING VANUIT 'N PASTORALE PERSPEKTIEF
}

\author{
Authors: \\ Elsona Malan ${ }^{1}$ \\ Yolanda Dreyer

\section{Affiliations: \\ ${ }^{1}$ Department Praktiese \\ Pretoria, Suid-Afrika} \\ Teologie, Universiteit van

\section{Correspondence to:} \\ Yolanda Dreyer \\ e-mail: \\ yolanda.dreyer@up.ac.za

\section{Postal address:} \\ Departement Praktiese \\ Teologie, Fakulteit \\ Teologie, Universiteit van \\ Pretoria, Lynnwoodweg, \\ 0083 Hatfield, Suid-Afrika
}

\section{Keywords:}

bejaardesorg

kerkouetehuise; ouer persone; sosiologiese; pastoraat

\section{Dates:}

Received: 10 Feb. 2009

Accepted: 23 Apr. 2009

Published: 11 Aug. 2009

How to cite this article: Malan, E. \& Dreyer, Y., 2009, 'Multidissiplinêre beskouinge op veroudering vanuit ' $n$ pastorale perspektief', HTS Teologiese Studies/ Theological Studies 65(1), Art. \#182, 9 pages. DOI: 10.4102/hts.v65i1.182

\section{This article is available} at: http://www.hts.org.za

\section{Nota:}

Hierdie artikel is ' $n$ verwerking van ' $n$ gedeelte van die MPhilverhandeling van $\mathrm{Dr}$ Elsona Malan, onder studieleiding van prof. $d r$ Yolanda Dreyer, ingedien en aanvaar deur die Universiteit van Pretoria in Oktober 2008

\section{(C) 2009. The Authors.} Licensee: OpenJournals Publishing. This work is licensed under the Creative Commons Attribution License.

\section{ABSTRACT}

Multiprofessional aspects of ageing seen from a pastoral perspective This article describes existing research on gerontology, and explores the role of pastoral care. When focusing on gerontology from a pastoral care point of view, certain multiprofessional aspects need to be considered. The article aims to highlight insights on the subject from the field of sociology, and to enable pastors to engage meaningfully with elderly persons. Reflection on the changing social environment emphasises the difficulties that retirement and the resulting loss of authenticity pose to the older person. The article considers how pastoral care as part of a multidisciplinary team could fulfil a positive role in gerontology.

\section{INLEIDING: VRAAGSTELLING}

Gedurende die tydperk 1970-1990 was die Nederduitse Gereformeerde Kerk, die kerk waartoe die navorser behoort, baie nou by ouer persone betrokke. Die regering het subsidies aan kerkouetehuise betaal; verblyf was voldoende, en uitgebreide families het goed gefunksioneer. Hierdie stand van sake het egter om verskeie redes verander (Theron 2006:2), onder meer die volgende:

- Die verstedelikingsproses weens ruimte- en finansiële beperkinge gee daartoe aanleiding dat kinders en ouers nie meer saamwoon nie

- Emigrasie van familielede bring mee dat ouer persone nie meer oor 'n ondersteuningstruktuur beskik nie

- Ouetehuisversorging word al hoe duurder omdat staatsubsidies verminder of gestaak is

- Aftree-oordverblyf word eweneens onbekostigbaar, en lang waglyste maak dit boonop moeilik bekombaar

- Weens die toenemende finansiële druk wat die toename in die getal ouer persone op die staat plaas, word bejaardesorg nie meer as voorrangsaak beskou nie

- As gevolg van geldtekorte, het die kerk ouetehuisbestuur aan gemeenskappe oorgelaat.

Hierdie faktore plaas groter verantwoordelikhede op nieregeringsorganisasies (NRO's) en veral kerke om saam met ander rolspelers praktiese oplossings te probeer vind. Die bejaardesorgkwessie is egter nie nét 'n praktiese aangeleentheid nie. Ook teoreties moet daar deeglik oor alle aspekte van veroudering en die persone wat daarby betrokke is, besin en nagedink word.

Op teologiese gebied maak so 'n teoretiese besinning deel uit van die dissipline Praktiese Teologie. Hoffman (1988:3) bevestig die dringendheid van so ' $n$ oordenking wanneer hy opmerk dat daar ' $n$ 'ooglopende gebrek aan ' $n$ breë teoretiese begronding vanuit die sosiale empirie is'. Volgens Hoffman is daar 'nog geen 'invloedryke' deelnemer in die multidissiplinêre gesprek met gerontologie nie'. Volgens Coetzer (2008) het die situasie met sy studie 'n paar jaar later steeds nie veel verander nie.

Die gebrek aan voldoende geestelike en maatskaplike leiers dra daartoe by dat die ouer generasie nie doeltreffende sosiale en geestelike sorg ontvang nie, welke tekortkoming in die multidissiplinêre span dit op sy beurt vir verpleegpersoneel moeilik maak om holistiese sorg te verskaf. ' $n$ Verdere probleem wat uit die literatuur blyk, maar nie in die praktyk suksesvol hanteer word nie, is die mishandeling en/ of verwaarlosing van ouer persone.

Op sosiologiese en maatskaplike gebied word ouer persone holisties as individue binne die breër samelewing beskou. Daar is egter 'n gebrek aan multidissiplinêre samewerking tussen maatskaplike werkers en versorgers in die verpleeg-/mediese beroep. Maatskaplike instellings beskik dikwels nie oor genoeg geld om die werk te laat voortgaan nie. Weens swak salarisse is daar baie vakante poste, en kan maatskaplike dienste nie na wense gelewer word nie. Die noodsaaklike voorbereidingsprogramme wat deur maatskaplike werkers ontwikkel en aangebied kan word, realiseer boonop nie altyd nie.

Die pastoraat as rolspeler in die versorging van ouer persone kom ook nie tot sy reg nie. In gesprekke met predikante het dit geblyk dat hulle nie altyd ten volle op hoogte is van ouer persone se behoeftes nie. Hulle is dikwels onseker oor die rol wat hulle werklik behoort te vervul. Die Nederduitse Gereformeerde Kerk (1990:199-223) se studie oor barmhartigheid voorsien nie bejaardesorgriglyne aan pastors nie. Netwerkvorming met die ander beroepe, en 'n multidissiplinêre benadering tot bejaardesorg, word wél teoreties bespreek, maar het prakties nog nie veel gevorder nie. Sake wat byvoorbeeld op hierdie gebied sou kon aandag kry, is aftreevoorbereiding, die uitskakeling van negatiewe opvattings oor ouer persone, en dienssentrumontwikkeling. Ouer persone se ervaring van rolverlies ná aftrede en namate hulle verswak, stel die pastoraat voor 'n besondere uitdaging. Pastors sou moontlik die insigte uit die sosiologiese navorsing sinvol kon benut om ouer persone in die proses van doeltreffende aanpassing in die samelewing met ander dog steeds sinvolle rolle te begelei.

Hierdie artikel stel dit ten doel om tot die verryking van pastors se kennis van die Gerontologie by te dra, en om hulle te help om ouer persone pastoraal beter te begelei. Die eerste deel van die artikel konsentreer op die sosiologiese insigte oor die onderwerp, en die belang van ' $n$ multiprofessionele 
benadering. Daarna volg ' $\mathrm{n}$ besinning oor die pastorale versorging van ouer persone.

\section{SOSIOLOGIE EN GERONTOLOGIE}

\section{Inleiding}

Gerontologie verwys na die studie van die ouderdom. Johnson (2000:133) beskryf dié dissipline soos volg: 'The study of aging is a biological, psychological and social process, especially as it results in problems of elderly people'. 'n Studie van veroudering sou dus die biologiese, psigologiese en sosiale dimensies van menswees van nader bekyk. Die sosiale dimensie van bejaardheid word in die onderafdeling van Gerontologie bestudeer wat as Sosiogerontologie bekend staan, en wat uitsluitlik aan sosiale faktore aandag skenk. Omdat kerk en samelewing deel uitmaak van die sosiale gebied van menswees, en godsdiens ' $n$ kernfaset van die samelewing is, is hierdie afdeling ook vir die pastoraat van belang. Sosiologiese insigte kan dus ' $n$ waardevolle bydrae tot sowel Gerontologie as die pastorale versorging van ouer persone lewer.

Johnson (2000:299) beskryf Sosiologie soos volg: 'Sociology is the study of social life and behaviour, especially in relation to social systems, how they work, how they change, the consequences they produce, and their complex relation to people's lives' (beklemtoning oorspronklik). Sosiologie is een van die groepe in die sosiale wetenskappe, en sluit ook Antropologie, Ekonomie, Politieke Wetenskap en Menslike Geografie in. Die verskillende sosiale wetenskappe kan egter nie klinkklaar afgebaken word nie, en dus is daar dikwels oorvleueling of grys gebiede (kyk Giddens 1993:746). Die fokus van Sosiologie, naamlik die verband tussen sosiale stelsels en individue se lewens, onderskei egter dié vakgebied van ander dissiplines. Ouer persone funksioneer nie as individue in afsondering nie, maar as deel van sosiale stelsels. Dit is juis op hiérdie gebied dat daar dikwels probleme met betrekking tot bejaardheid ontstaan. Sosiologiese insigte dra dus by tot ' $n$ beter gerontologiese begrip van die sosiale aspek van bejaardheid, en die sosiale probleme wat met veroudering ontstaan.

Die ontwikkeling van sosio-gerontologie het in verskeie fases plaasgevind. Gedurende die tydperk 1920-1940 is die veelvuldige probleme van armoede en depressie by ouer persone beklemtoon, en is daar na praktiese oplossings gesoek om die lewensverwagting van ouer persone te verbeter. Destyds het die gemiddelde persoon maar ongeveer 45 jaar oud geword. Verskeie teorieë is tussen 1940 en 1960 ontwikkel om die proses van veroudering te beskryf, bejaardheid te omskryf, en bestaande teorieë te verbeter.

Gerontologiese sosiologiese navorsing kan in makro- en mikrodimensies verdeel word. Die mikrodimensie beklemtoon ouer persone se lewenservaring, afhanklikheid, rolaanpassing en sosiale wisselwerking, terwyl aspekte soos losmaking, veroudering en sosiale aftakeling ook aangeroer word. Die makrososiologiese dimensie van Gerontologie het te doen met demografiese veranderings, breë verhoudingstelsels, en die ontleding van organisasies en regeringsbeleid, sowel as teorieë oor ouderdomstratifikasie, konflik, politiek en die ekonomie. Die sosioloog Johnson beskryf die sosiale uitwerking van veroudering soos volg:

Chronological aging is the universal biological process and experience that affects everyone over time. Social aging is a far more complex process that involves the passage from one social position to another. This brings new rights and responsibilities and a changing social identity. All societies divide the life course into a series of age categories, each of which is associated with various cultural ideas about who people are, what they can do, and what is expected of them in relation to other people.

(Johnson 2000:299)

Veroudering word dus allerweë as ' $\mathrm{n}$ ingewikkelde proses beskou wat op sosiale gebied nuwe regte en verantwoordelikhede meebring. Veroudering kom nooit in 'n sosiale vakuum voor nie, maar word deur verskeie sosiale prosesse en strukture beïnvloed. Die feit dat samelewings daartoe geneig is om individue te kategoriseer, hou altyd die gevaar van stereotipering in. Dit kan dan ook maklik op diskriminasie en vooroordeel teenoor ouer persone uitloop. Ouderdomsdiskriminasie en -vooroordeel (ageism) is volgens Johnson 'n groot knelpunt in die verouderingsproses:

Ageism is prejudice based on differences in age. Unlike most other forms of prejudice, ageism affects everyone at one time or another since everyone spends time in both subordinate (such as childhood) and dominant (such as middle-age) age categories.

(Johnson 2000:6)

Diskriminasie of vooroordeel is vir sosioloë van belang omdat dit ongelykmatige hantering van ouer persone meebring. Die literatuur plaas deurlopend klem op die verskuiwing vanaf die tradisionele samelewing, waar ouer persone nog aansien geniet het, na die huidige bedeling waarin bejaardes aan diskriminasie onderwerp word. Die sosioloog Anthony Giddens (1993:85) verduidelik die sosiale dilemma van ouer persone soos volg:

'No longer living with the children, ejected from the economic arena, it is not easy for older people to make the final period of their life rewarding'

Dít stel die multidissiplinêre span wat ouer persone moet ondersteun en versorg voor groot uitdagings.

\section{Teorieë oor veroudering uit die Sosiologie}

Sosiologiese navorsing ten opsigte van die verouderingsproses is toegespits op die negatiewe sosiale omstandighede waarin ouer persone hulle bevind, en soek derhalwe na oplossings. Die doel is om individue langer gesond en aktief te laat bly. Hiervoor doen Kastenbaum (1993:319) aan die hand dat die oplossing stellig in die verband tussen ouderdomsdiskriminasie en verouderingsteorieë lê: 'Despite the limitations and difficulties that have been noted, it is still useful to explore possible connections between ageism and theories of aging.' Vervolgens word ' $\mathrm{n}$ sosiologiese teorie wat tot 'n beter begrip van outentieke veroudering kan bydra, naamlik die aktiwiteitsteorie, kortliks bespreek.

\section{Aktiwiteitsteorie}

Volgens die aktiwiteitsteorie van Neugarten, Havighurst en Tobin (1961:134-143) sal ouer persone wat aktief bly suksesvoller verouder. Dit geld eintlik ook die generasie ná hulle, naamlik middeljariges. Ray en Heppe (1986:31-44) wys daarop dat 'self concept' ' $n$ kern aangeleentheid in die 'aktiwiteitsteorie' wat tot lewensvervulling lei. Die aktiwiteitsteorie gaan dus oor meer as net ouer persone se aktiwiteite en bydraes tot die samelewing. Aktiwiteite' verwys ook na informele aktiwiteite op persoonlike vlak met vriende of bure, formele aktiwiteite ter ondersteuning van vrywillige organisasies, sowel as ontspanningsaktiwiteite. Al hierdie bedrywighede is belangrik om rolondersteuning en die versterking van die selfbegrip by ouer persone in die hand te werk. Die teorie gaan dus in wese oor ouer persone se betrokkenheid by die samelewing.

Die waarde van die aktiwiteitsteorie is beperk - aktiewe betrokkenheid alleen waarborg immers nie suksesvolle aanpassing nie. Faktore soos aftrede, verlies aan inkomste, gesondheid, weduwee-/wewenaarskap, en die rolverandering in die gesin is faktore wat verder daartoe kan bydra dat die ouer persoon al hoe meer aan die samelewing begin onttrek. Rosow beskryf die uitwerking van rolverlies op veral weduwees se samelewingstatus soos volg:

... the loss of roles is mainly involuntary and unwelcome, even when illness forces retirement. Role losses inevitably affect previous group memberships, lower prestige and reduce one's status sets and the social integration that they provide the individual

(Rosow 1974:9)

Rolverlies lei tot minder verantwoordelikhede en beperkte aktiwiteit. Hoffman (1988:10-41) dui daarop dat aktiewe betrokkenheid deur ouer persone nie simplisties beskou kan 
word nie. Ouer persone se aktiwiteit kan nie volgens die norme vir middeljariges beoordeel word nie, omdat daar in bejaardes se geval heelwat ander bepalende faktore is. Kwessies wat byvoorbeeld in bejaardheid ' $n$ besondere rol speel, is die ouer persoon se verhouding met God, sowel as hulle veranderde verhouding tot die kultuur en ander mense. Die ideaal is dus dat bejaardes op alle gebiede vlot en geïntegreerd by veranderde omstandighede sal aanpas.

Die waarde van die aktiwiteitsteorie is die klem op die invloed van rolverlies op ouer persone, sowel as die voorgestelde aanpassings wat volgens die teorie nodig blyk te wees. Om aktief te wees en te bly, is noodsaaklik vir lewensgehalte. Die ontginning van nuwe aktiwiteite vir oud én jonk kan moontlik die negatiewe stereotipering van die bejaarde uit die weg ruim, en aktiewe betrokkenheid aanmoedig. Hierdie ontginning van ander moontlike sinvolle aktiwiteite kan deel word van die taak van die pastor en die geloofsgemeenskap ten opsigte van die versorging van ouer persone. Geloofsgemeenskappe hou deesdae al hoe meer werksessies oor die ontdekking en ontwikkeling van gawes of sterk punte.

Dít kan vir ouer persone in die besonder van waarde wees. Die meeste afgetredenes streef daarna om by aktiwiteite betrokke te raak wat hulle 'n gevoel van nut laat beleef. Volgens Wilhelm Coetzer (2008) behoort die kerk geen uitsonderings te maak op grond van ouderdom nie. Gelyke verantwoordelikhede en geleenthede tot dienslewering geld vir almal. Dit kan tot lewensverryking lei. Die bemagtiging van die ouer persoon om aan aktiwiteite deel te neem, is dus noodsaaklik.

\section{Teorieë oor veroudering uit die Psigologie en Gerontologie \\ Persoonlikheidsteorieë}

Psigologiese persoonlikheidsteorieë berus daarop dat mense se persoonlikheid bepaal hoe suksesvol hulle by die samelewing aanpas. Dít is by uitstek waar vir ouer persone wat voor die uitdaging te staan kom om by noodwendige dog soms ongewenste verandering in hulle lewens aan te pas. Volgens die persoonlikheidsteorieë hang outentieke of suksesvolle veroudering af van ouer persone se inherente vermoë om by verskillende lewensituasies aan te pas en hulle lewenspatroon voort te sit. Ten opsigte van bejaardheid onderskei Neugarten, Moore en Lowe (1965) tussen die geïntegreerde persoonlikheid, die verdedigende persoonlikheid, en die ongeïntegreerde persoonlikheid.

Ouer persone met ' $n$ geïntegreerde persoonlikheid beskik oor ' $n$ hoë vlak van tevredenheid met hulle lewensituasie en bestaande rolle, en funksioneer steeds goed op kognitiewe vlak. Mense met ' $n$ verdedigende persoonlikheid is ambisieus. Hulle floreer op uitdagings, en openbaar ' $n$ hoë weerstand teen angs. Die negatiewe sy van hierdie persoonlikheidstipe is egter dat hulle daartoe geneig is om aan rolsituasies uit die verlede vas te klou. Sulke persone is rolafhanklik, en het deurlopende ondersteuning en aanmoediging nodig. Persone met ' $n$ ongeïntegreerde persoonlikheid sukkel om hulle emosies te beheer. Sulke persone se denkprosesse gaan agteruit, hulle handhaaf ' $n$ betreklik lae vlak van rolaktiwiteit, en is passief en afhanklik.

'n Kritiese beoordeling van hierdie persoonlikheidsteorie vir bejaardheid toon egter dat dit nie sonder meer, sonder inagneming van ander faktore, toegepas kan word nie. So byvoorbeeld speel die samelewing se sosiale invloed op die individu ook ' $n$ rol. Alles hang nie net van die ouer persoon se persoonlikheid af nie. Die waarde van dié teorie is die klem op 'n ontwikkelingsproses van individuele persoonseienskappe. Hill beskou die persoonlikheidsteorieë soos volg:

... for the most part, personality traits are not amendable to change; however, counseling strategies may be effective in altering some of the external manifestations of behaviour or cognitive sequela that results from these traits

(Hill 2005:118)

\section{Onttrekkingsteorie}

Volgens die onttrekkingsteorie is dit normaal vir ouer persone om hulle aan die samelewing te onttrek (kyk Cumming \& Henry 1961). Die veronderstelling van die teorie, naamlik dat ouer persone mettertyd aan die samelewing móét onttrek weens ' $n$ afname in energie, en omdat jonger persone bejaardes se rolle moet oorneem, word egter bevraagteken. Dit is nie vir alle ouer persone nodig om te onttrek ten einde sinvol te verouder nie. Talle ouer persone vervul nog op 80 en ouer ' $n$ aktiewe rol in die samelewing. Geen twee mense, en veral ouer persone, is dieselfde nie, en individualiteit kan nie geïgnoreer word nie. Die proses van onttrekking is nie soseer wenslik nie, maar wél onvermydelik. Bepaalde lewensituasies moet hier in ag geneem word. Onttrekking kom meer algemeen by ouer persone as by jonger bejaardes voor.

Die redes waarom ouer persone onttrek, is omstandighede soos die dood van ' $n$ vriend of ' $n$ eggenoot, en die daaropvolgende verlies van verblyf. Dikwels noop sulke omstandighede bejaardes om na ' $\mathrm{n}$ ander omgewing te verhuis, en onttrek hulle gevolglik aan die samelewing (Johnson 2000:91). Onttrekking weens die verlies van ' $\mathrm{n}$ lewensmaat is normaal, aangesien so ' $n$ verlies alleenlik met verloop van tyd verwerk kan word. Volgens literatuur (kyk Cumming \& Henry 1961) is dié onttrekking meestal tydelik. Nóg 'n 'normale' reaksie is as ouer persone weens familiebetrokkenheid onttrek, byvoorbeeld om kleinkinders op te pas, of om by portuurgroepe betrokke te raak.

Die waarde van hierdie teorie is die klem op die sosiale proses waardeur ouer persone hulle weens hoë ouderdom onttrek om vir die jonger geslag plek te maak (Giddens 1993:615). Insigte van hierdie teorie kan die pastor en geloofsgemeenskap help om ouer persone wat deur hierdie proses gaan beter te ondersteun en met die skep van alternatiewe rolle by te staan. Ouer persone sal op die onttrekkingsproses voorberei en daarin ondersteun moet word, veral wanneer die verlies van 'n lewensmaat en/of vriende dit aanbring.

\section{Kontinuïteitsteorie}

Volgens Neugarten, Moore en Lowe (1965:710-717) bly persoonlikheid en gedragspatrone in ' $n$ groot mate onaangeraak deur veroudering. Karaktertrekke wat met verloop van jare ontwikkel, sal nie in die verouderingsproses verander nie. Hierdie insig is belangrik vir jonger geslagte - hulle geneigdhede en gedrag in hulle jeug sal derhalwe tot in lengte van dae so bly. In teenstelling met die onttrekkingsteorie, wat rolverlies as normaal beskou, reken die kontinuitteitsteorie dat verlore rolle deur nuwe rolle vervang behoort te word.

Die kontinuïteitsteorie is volgens Hill (2005:35) op 'n sosiaalpsigologiese teorie van veroudering gegrond, wat daarop berus dat persone se identiteit in die verouderingsproses geraak word deur hulle selfbeskouing en faktore wat die stabiliteit van sodanige selfbeskouing beïnvloed. Robert Atchley beskryf die kern van dié teorie soos volg:

Continuity theory describes the role that consistency, or a lack thereof, plays in defining one's sense of the self as an 'older person'.

(Atchley 1989:37)

Die grondslag van interne kontinuïteit is in stabiele interpersoonlike kenmerke geleë wat tot aanpasbaarheid by die omgewing bydra, en wat versteur kan word wanneer ouer persone byvoorbeeld hulle werk verloor. Eksterne kontinuïteit het met die stabiliteit van die eksterne omgewing te doen. Wanneer ' $n$ ouer persoon byvoorbeeld nie meer motor mag bestuur nie, kan dié verlies aan beheer oor die eksterne omgewing ' $n$ traumatiese ervaring wees. ' $n$ Rybewys gee immers die ouer persoon ' $n$ gevoel van onafhanklikheid. Sowel interne as eksterne kontinuilteit verteenwoordig stabiele kragte wat ouer persone in staat stel om die uitdagings en probleme van veroudering te hanteer. 
'n Belangrike element van die kontinuïteitsteorie is die konsep 'diskontinuïteit', wat gebeure van sowel interne as eksterne oorsprong behels wat die individu onverwags kan beïnvloed. Diskontinuïteit kan positief of negatief wees. Positiewe diskontinuïteit kan plaasvind wanneer interne en eksterne veranderings aangenaam of wenslik is, byvoorbeeld die wen van die lotery. Negatiewe diskontinuïteit is veranderings wat ongunstig beleef word en angs en depressie kan veroorsaak Ouer persone se toenemende besef van die werklikheid van die dood kan byvoorbeeld so 'n uitwerking hê. 'n Ander voorbeeld is die trauma en spanning verbonde aan verhuising na ' $n$ ouetehuis.

Om positiewe kontinuïteit te verseker, en die aanpassing te vergemaklik, kan bejaardes se eie meubels en portrette dalk 'n plek in die ouetehuiskamer vind, en kan daar moeite gedoen word om hulle belangstellings, stokperdjies en kosvoorliefdes in ag te neem. Elke mens het eiesoortige voor- en afkeure. Indien dit in ag geneem word, en versorgers hulle daarop toespits om kontinuïteit vir die ouer persoon te help skep, kan dit die persoon se aanpassing by nuwe omstandighede vergemaklik. Hill (2005:44) stel dit soos volg:

The strengths of using principles of continuity theory interventions to facilitate physical or emotional adjustments during transitions are apparent.

Hill (2005:44)

Hierdie teorie hét sy beperkinge, maar kan wél goed benut word deur spanlede op die individu, sy/haar voorkeure, en hoe dit met sy/haar sorgbehoeftes verband hou, te laat konsentreer.

Die kontinuïteitsteorie berus op die beginsel van stabiliteit in die individu se lewe. Verandering, of aanpassing by verandering, behels die aanwending van bestaande psigologiese hulpbronne om toekomstige probleme op te los. Dit is egter belangrik om te besef dat ouer persone ondersteuning nodig het om hierdie aanpassings suksesvol te maak.

\section{Selektiwiteit, optimalisering en kompensasie (die SOC-teorie)}

Die SOC- (Selectivity Optimisation Compensation-)teorie het optimale volwasse ontwikkeling in die oog (Baltes 1997), en kan van groot nut op die gebied van Gerontologie wees. Selektiwiteit dui op die vermoë van volwasse (en dus ook ouer) persone om te kies waaraan hulle hulle energie wil bestee. Ouer persone kan byvoorbeeld besluit om meer tyd aan familie as aan vriende af te staan. Optimalisering gaan oor die keuse om byvoorbeeld nuwe vaardighede aan te leer, of meer tyd aan funksionele aktiwiteite te bestee, om daarmee ' $n$ groter bydrae tot die samelewing te maak. Deur intensiewe geheueskoling kan ouer persone byvoorbeeld leer om hulle kwynende geheue ten beste te benut (te optimaliseer). Kompensasie verwys na daardie vermoëns wat normaalweg met ouderdom verswak, en die maniere waarop bejaardes daarvoor kompenseer, soos byvoorbeeld deur ' $\mathrm{n}$ bril of gehoorapparaat te begin dra.

Die kern van die SOC-teorie is dat elke persoon oor latente reserwevermoëns beskik. Wanneer hierdie onontginde vermoëns ontdek word, kan dit help om die verouderingsproses 'n meer positiewe weg te laat volg (Hill 2005:46). Die teorie beskryf bepaalde meganismes wat met aanpassing in die samelewing kan help, en kan ook op veroudering toegepas word. Hill beskryf die teorie se waarde vir veroudering soos volg:

With respect to what makes SOC work, the more effective an individual is at employing the processes of selectivity, optimization and compensation to facilitate adaptation, the better a person will deal with the challenges and issues of growing old.

(Hill 2005:50)

Bogenoemde teorieë, soos dit op veroudering toegepas word, is daarop gemik om ' $n$ raamwerk vir gesonde veroudering te bied. Presies hóé 'n persoon gaan verouder, hang egter af van die betekenis wat hy/sy aan die onafwendbare lewensproses van veroudering toeken.

\section{Samevatting}

Uit voormelde teorieë blyk dit duidelik dat veroudering 'n dinamiese proses is wat nie aan slegs enkele faktore toegeskryf kan word nie. In die pre-industriële kulture is ouer persone hoog geag, maar in die moderne samelewing word daar minder van hulle verwag. Dit het ' $n$ negatiewe uitwerking op ouer persone se psige, en kan tot 'n minderwaardigheidsgevoel, apatie en onttrekking lei. Die aktiwiteitsteorie beklemtoon dat ouer persone wél iets kan doen om steeds sinvol deel van die samelewing te bly. Die onttrekkingsteorie konsentreer daarop dat ouer persone sélf oor die mate van onttrekking kan besluit, en dat selfs al sou omstandighede hulle dwing om te onttrek, dit in baie gevalle slegs tydelik hoef te wees. Die kontinuitteitsteorie stel die waarde van interne en eksterne kontinuitteit te midde van veranderende omstandighede voorop, terwyl die SOC-teorie oor die moontlikheid handel om nie net by omstandighede aan te pas nie, maar om lewensgehalte doelbewus te optimaliseer en te kies.

Presies wat goeie lewensgehalte behels, is nog nie duidelik nie. Daar ís egter reeds bepaal dat ontspanning, opvoedkundige aspekte en geestelike ondersteuning 'n groot bydrae daartoe lewer. Wanopvattings en stereotipes ten opsigte van ouer persone moet so ver moontlik op sistemiese en individuele vlak bestry word om optimale veroudering in die hand te werk. Riley, Hess en Bond voer aan dat ouderdom sosiaal gekonstrueer word:

Research already shows the power of factors social, cultural and economics. It shows that aging and the status of the elderly are not inevitably fixed but are subject to social modification and change, but more research is needed as to how these functions operate.

(Riley, Hess \& Bond 1983:1)

\section{DIE MULTIPROFESSIONELE SPAN}

Volgens Zastrow (2004:5) is Maatskaplike Werk sowel 'n instelling as ' $\mathrm{n}$ beroepsdissipline. Die Nuwe Woordeboek vir Maatskaplike Werk (Le Roux 1995:40) omskryf Maatskaplike Werk as ' 'n professionele diens wat deur 'n maatskaplike werker gelewer word wat gerig is op die bevordering van die maatskaplike funksionering van mense'. Hierdie diens is toegespits op verhoudings, aanpassingsprobleme, armoede en behuisingsprobleme. Maatskaplike welsyn op sy beurt 'is ' $n$ toestand wat die mate van voorspoed, welstand en gesondheid in 'n samelewing bepaal, asook die geleenthede vir ontwikkeling en bevrediging van behoeftes van selfverwesenliking wat vir groepe en gemeenskappe bestaan' (Le Roux 1995:39).

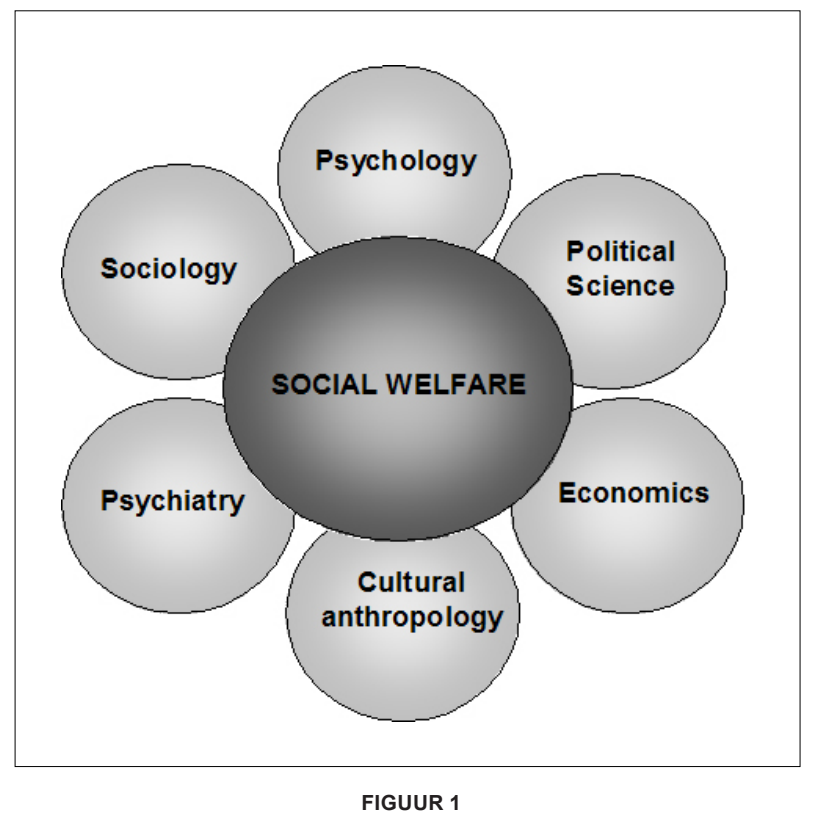

Kennisbasis-oorvleueling van maatskaplike welsyn met ander dissiplines 


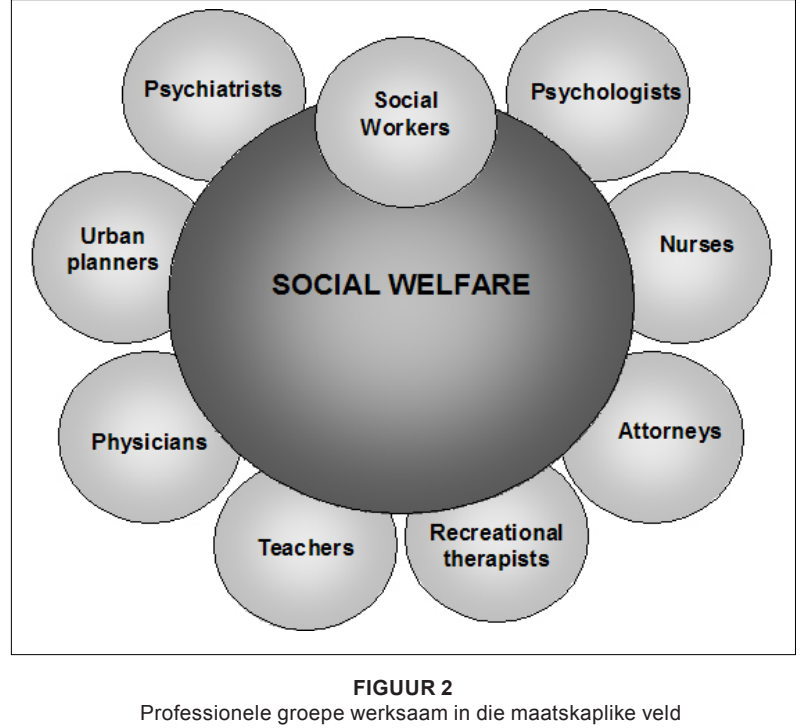

Maatskaplike welsyn het 'n sterk ekonomiese en politieke grondslag, en maak deel uit van verskeie beroepsvelde. Maatskaplike welsynsbehoeftes behels dus die behoeftes van individue, gesinne, groepe of gemeenskappe wat hulle maatskaplike funksionering beïnvloed (Le Roux 1995:38).

Die maatskaplike welsynstruktuur behels die fasiliteite en stelsels in die samelewing, byvoorbeeld welsynsorganisasies, welsynsinstansies en die geskikte menslike hulpbronne en finansiële strukture, wat nodig is vir die lewering van ondersteunende maatskaplike welsynsdienste. Dikwels word maatskaplikewelsynmetSosiologieenandergeesteswetenskappe verwar. Dít gee aanleiding tot die vraag oor watter verwantskap daar tussen Maatskaplike Werk en ander sosiale wetenskappe, soos Sielkunde en Psigiatrie, en dergelike dissiplines bestaan. Figuur 3.1 beeld dié verwantskappe uit (Zastrow 2004:6):

Die onderskeie dissiplines ontwikkel ' $n$ kennisbasis ten opsigte van maatskaplike probleme, die oorsake daarvan, sowel as die ingrypings wat kan plaasvind. Volgens die skets is daar ses dissiplines wat Maatskaplike Werk se kennisbasis aanvul. Dié ses het almal hulle eie kenmerkende fokus. Sosiologie is die studie

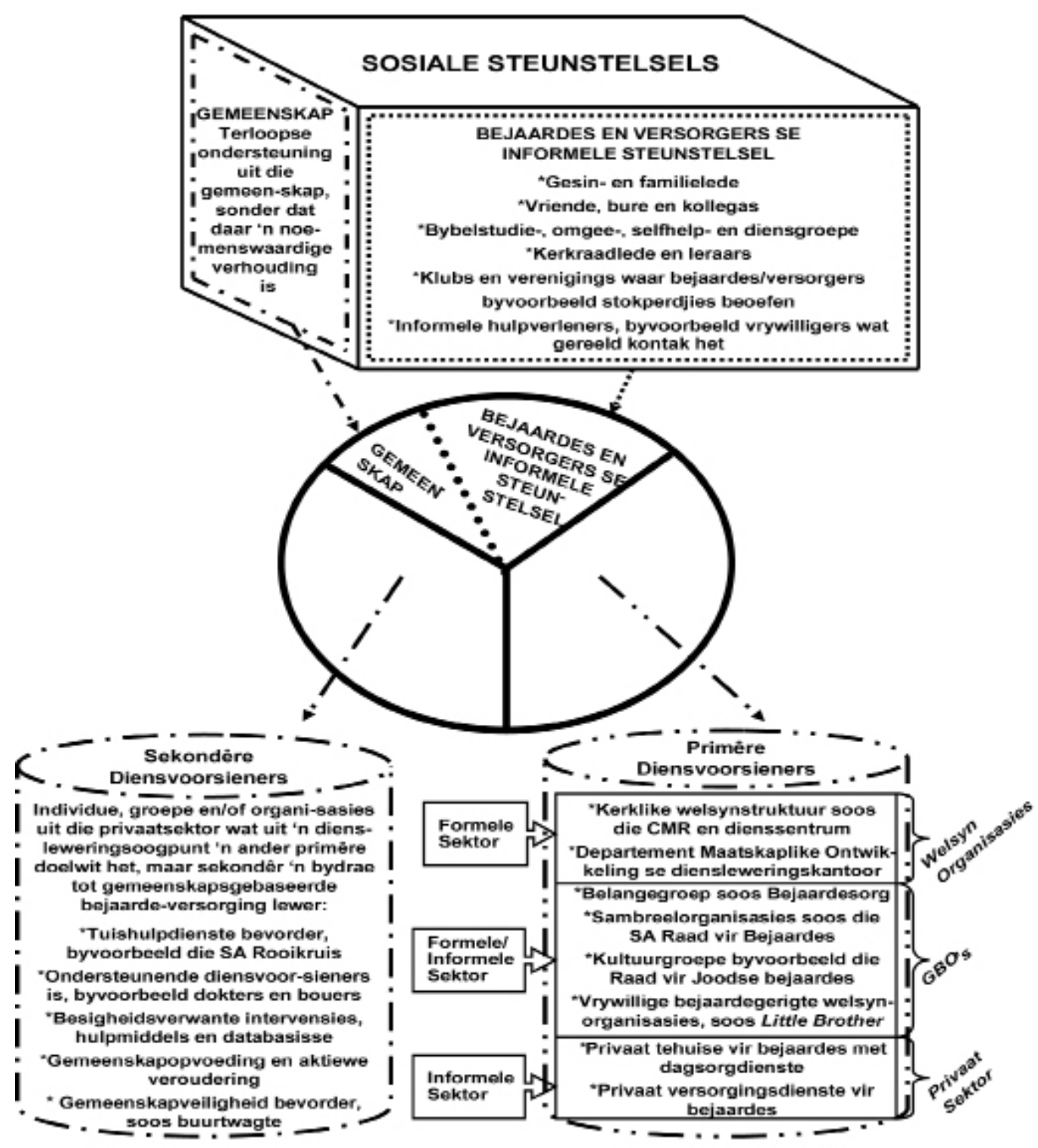

FIGUUR 3

Rolspelersin gemeenskapsgebaseerde bejaardesorg 
van menslike sosiale gedrag, veral ten opsigte van die oorsprong, organisasie, instellings en ontwikkeling van die menslike samelewing. Sielkunde is die studie van geestelike prosesse en gedrag. Psigiatrie is die studie van die diagnose, behandeling en voorkoming van geestesiektes. Politieke Wetenskap is die studie van die prosesse, beginsels en strukture verbonde aan regerings en politieke instellings. Ekonomie is die studie van produksie, verspreiding en verbruik. Kulturele Antropologie is die studie van menslike kultuur op grond van argeologiese, sosiale, psigologiese en etnografiese data en ontledingsmetodes (Zastrow 2004:6). In die verlede is Maatskaplike Werk as ' $n$ toegepaste wetenskap beskou omdat dit op wetenskaplike gebied van hierdie ander dissiplines afhanklik was. Navorsing en teorieontwikkeling het egter daartoe bygedra dat Maatskaplike Werk vandag as ' $n$ volwaardige dissipline beskou word.

Wat die multidissiplinêre span gemoeid in bejaardesorg betref, moet die volgende voorstelling van dissiplines wat by dienslewering met die oog op maatskaplike welsyn betrokke is na regte ook nog paramediese rolspelers, aptekers, dieetkundiges en pastorale dissiplines insluit (kyk Zastrow 2004:7).

\section{'n Toekomsblik}

Die toekoms en aard van Maatskaplike Werk sal hoofsaaklik deur tegnologiese vooruitgang beïnvloed word. Veral ten opsigte van ouer persone meen navorsers dat onderstaande faktore ernstige uitdagings aan maatskaplike dienslewering sal stel (kykZastrow 2004:24):

- Oorbevolking, veral in stede, weens byvoorbeeld die gebrek aan mediese dienste op die platteland

- Armoede weens byvoorbeeld stygende mediese, voedsel- en verblyfkoste en onvoldoende pensioene

- $\quad$ 'n Beter lewensverwagting weens goeie mediese sorg

- Verblyfknelpunte, veral ten opsigte van ' $n$ tekort aan beddens in aftree-oorde en ouetehuise

- Rolverlies weens vroeër aftrede

- Gesondheidsprobleme as gevolg van ondervoeding, emosionele probleme en mishandeling

- Verwaarlosing en selfs mishandeling deur kinders, wat tot sosiale afsondering aanleiding gee

Wat die toekoms van maatskaplike dienste betref, waarsku Zastrow soos volg:

What the future will hold is difficult to predict accurately. The worst mistake, however, is to take the 'ostrich head in the sand' approach in which no effort is made to plan and control the future.

(Zastrow 2004:24)

Daadwerklike optrede ten opsigte van die uitdagings is noodsaaklik, en alle diensvlakke sal moet saamwerk om in die behoeftes van ouer persone te voorsien.

Soos reeds aangedui, val die klem sowel nasionaal as internasionaal al hoe meer op die versorging van ouer persone. Hoewel die hoofverantwoordelikheid vir bejaardesorg in Suid-Afrika na die gemeenskap verskuif het, aanvaar die staat steeds ' $\mathrm{n}$ bepaalde verantwoordelikheid in hierdie verband (Claassen 2001:51). Die lewering van 'n doeltreffende gemeenskapsgebaseerde diens vereis die vorming van vennootskappe tussen die regering, primêre en sekondêre diensverskaffers, en die maatskaplike steunstelsels van ouer persone. Volgens Claassen (2001:51) is dit van belang dat ouer persone in gemeenskapsverband begryp word ten einde ingrypings te bewerkstellig wat ' $n$ betekenisvolle bydrae tot gemeenskapsgebaseerde bejaardesorg kan maak. Verskeie faktore beïnvloed die funksionering van ouer persone in die gemeenskap. Ouer persone het byvoorbeeld met voortdurende persoonlike verlies te kampe, soos die verlies van sig, en die gepaardgaande verlies aan onafhanklikheid wanneer die persoon nie meer mag motor bestuur nie; die emigrasie van kinders, en sosiale verliese weens fisieke verswakking. Verblyf word eweneens ' $n$ probleem weens die onbekombaarheid en onbekostigbaarheid van plek in aftree-oorde en ouetehuise. Ouer persone se finansiële posisie verswak weens stygende lewens- en mediese koste en die ouderdomskrisis van gevorderde jare. Hulle verlies aan lewenskragtigheid veroorsaak ' $n$ groter behoefte aan ondersteuningsnetwerke, byvoorbeeld vir kosvoorsiening en vervoer. Viktimisering van ouer persone noodsaak ook dikwels toesighouding en beheer (Claassen 2001:52-74).

Hierdie faktore lei tot angs en spanning by ouer persone, en het 'n negatiewe uitwerking op hulle gevoel van veiligheid en sekuriteit. Die feit dat hulle ondersteuningsnetwerk verswak, en dat daar nie voldoende bekostigbare gemeenskapsdienste bestaan nie, dompel ouer persone in ' $n$ krisis. Die informele steunstelsels van die ouer persoon word ook al hoe belangriker. Om suksesvolle hulpstelsels tot ouer persone se beskikking te stel, moet maatskaplike werkers op die hoogte wees van die stand van sake, en na gelang van maatskaplike nood in bejaardes se behoeftes voorsien.

Die ouer persoon kan nie sonder sowel formele as informele steun nie, en figuur 3 (Claassen 2001:176) dui derhalwe die rolspelers aan wat netwerke vir gemeenskapsgebaseerde bejaardesorg moet vestig.

Informele steunstelsels sluit lede van die gemeenskap in wat toevallig en sonder veel persoonlike verbondenheid by bejaardesorg betrokke is, terwyl gesins- en familielede, vriende, bure en kollegas ook bejaardesteun verleen. Onder hierdie kategorie val ook ondersteuning wat uit kerklike betrokkenheid spruit, byvoorbeeld Bybelstudie-, omgee-, selfhelp- en diensgroepe. Geloofsgemeenskappe behoort dié groepe met kennis van hulle diensleweringsverantwoordelikheid toe te rus. Kerkrade en leraars bied boonop ondersteuning aan ouer persone. Kerke sal voortaan in ' $\mathrm{n}$ toenemende mate hulle verantwoordelikheid ten opsigte van ouer lidmate moet aanvaar, aangesien hulle (kerke) oor die ideale infrastruktuur en kontakte op gemeenskapsvlak beskik om tuisversorging aan te voor. Dagsorgklubs en dienssentra kan ook oorweeg word. Dienssentra is nieresidensiële geriewe wat in baie van die ouer persoon se behoeftes kan voorsien. Met dié hulpdienste word daar verseker dat ouer persone so lank moontlik in hulle eie woonplek kan aanbly. Die aanvoor van tuisversorgingsdienste deur informele versorgers is nóg ' $n$ uitdaging vir die kerk.

Hierdie dienste kan saam met ander rolspelers beplan word. Hulpbronne moet aangewend word vir veiligheidsnetwerke sowel as die aanbied van misdaadvoorkomings-programme ten einde ouer persone te beskerm. Deelname aan klubs wat deur die kerk gestig word om byvoorbeeld stokperdjies te beoefen, moet by die ouer persoon aangemoedig word om sosiale afsondering te voorkom. Claassen verwoord dié uitdaging waarvoor die kerk staan soos volg:

... Kerklike betrokkenheid, gemeentelike inisiatiewe, omgeegroepe, gerontologieseopleiding, uitreikprogrammenabejaardes, konsultasie en koördineringsdiens ten opsigte van "gemeenskapsgevalle" is voorbeeldevaninformelegemeenskapsgebaseerdebejaardeversorging - inisiatiewe wat deur die godsdienssektor geïmplementeer kan word.

(Claasen 2001:218)

Hierdie uitdaging sal so spoedig moontlik aangepak moet word. Primêre diensverskaffers word in ' $\mathrm{n}$ formele en informele sektor verdeel. Die formele sektor lewer hoofsaaklik deur welsynsorganisasies ' $n$ diens aan ouer persone. Formele strukture sluit kerklike welsynstrukture soos die Christelike Welsynsraad (CWR) van die Nederduitse Gereformeerde Kerk se dienssentra sowel as die Departement Maatskaplike Ontwikkeling in. In kerkverband verskaf maatskaplike werkers gemeenskapsgebaseerde sorg. Verskeie kundige maatskaplike werkers van die CWR en die Sinodale Kommissie vir die Diens van Barmhartigheid dien op verskeie vlakke in die Sinode van die Nederduitse Gereformeerde Kerk, terwyl beroepslui soos geriatriese maatskaplike werkers by verskeie kerkrade betrokke is. Die informele sektor bestaan op sy beurt uit belangegroepe 
soos Bejaardesorg, 'Age-in-Action' (wat voor 2001 as die SuidAfrikaanse Raad vir Bejaardes bekend gestaan het) sowel as verskeie kultuurgroepe. Die privaat sektor verskaf boonop privaat tehuise met dagsorgdienste en privaat versorgingsdienste vir ouer persone.

Sekondêre diensverskaffers bestaan hoofsaaklik uit individue, groepe en organisasies uit die gemeenskap en privaat sektor, soos byvoorbeeld die Rooikruisvereniging se tuishulpdienste, ondersteunende diensverskaffers soos dokters en bouers, sowel as buurtveiligheidswagte wat gemeenskapsveiligheid in die hand werk.

\section{Samevatting}

Dit is noodsaaklik dat die samelewing ' $\mathrm{n}$ betekenisvolle, produktiewe rol vir die ouer persoon verseker. In die voorafgaande bespreking is die onderskeie rolspelers in gemeenskapsgebaseerde bejaardesorg bespreek. Die faktore wat ouer persone se funksionering in die gemeenskap kan beïnvloed, is ook uitgelig. In Suid-Afrika bied die Witskrif vir Maatskaplike Welsyn (Departement Welsyn 1997), die Finansieringsbeleid vir Ontwikkelingsgerigte Maatskaplike Welsynsdienste (Departement Welsyn 1999) en die Wet op Ouer Persone, Wet 13 van 2006 (Suid-Afrika 2006) die raamwerk vir gemeenskapsgebaseerde dienslewering.

Die Departement Maatskaplike Ontwikkeling en die rolspelers van die Departement lewer ' $\mathrm{n}$ besondere bydrae ten opsigte van die uitvoering van bostaande beleid en wetgewing. Sonder die Departement se diens kan Suid-Afrika nie die nodige ondersteuningsnetwerke vir bejaardes aanvoor nie, maar ongelukkig gaan hulle soos baie ander staatsdepartemente onder personeeltekorte gebuk. So byvoorbeeld bedien een maatskaplike werker in ' $n$ halfdagpos wat deur die kerk gefinansier word vier kerke. Bejaardes se probleme word hoofsaaklik na Age-in-Action verwys, aangesien maatskaplike werkers merendeels op kinders en onderhoud konsentreer, en gevolglik weinig tyd oor het om ondersteuning aan die ouer persoon te bied.

Oor die jare het die vakdissipline Maatskaplike Werk gepoog om 'n wetenskaplik verantwoordbare beskouing van bejaardheid te bekom. Dít is uiteindelik deur middel van navorsing ontwikkel, en daarom word ouer persone vandag as ' $n$ eenheid van liggaam, siel én gees beskou. Die doel is om saam met die ander vakdissiplines deur onderskeie netwerke gemeenskapsgebaseerde dienslewering tot stand te bring sodat ouer persone so lank moontlik veilig en selfstandig deel van die samelewing kan bly. Die pastoraat kan in hierdie verband ' $\mathrm{n}$ betekenisvolle rol vervul.

\section{PASTORALE VERSORGING}

\section{Inleiding}

Bejaardesorg het tot ' $n$ belangrike spesialisgebied ontwikkel wat steeds omvattende aanpassings beleef. Weens die verandering in die gesondheidsbeleid oor ouer persone (Suid-Afrika 2006) het kerke ' $n$ belangrike rolspeler geword. Dít geld nie net formele dienslewering deur middel van byvoorbeeld die Christelike Welsynsraad van die Nederduitse Gereformeerde Kerk, en dienssentra en bejaardetehuise van die kerk nie, maar in die besonder ook pastorale versorging van ouer persone op ' $\mathrm{n}$ informeler vlak in geloofsgemeenskappe. Die pastoraat fokus nie meer net op individuele berading deur die pastor nie, maar word eerder as die werkplek van geloofsgemeenskappe beskou. Gerkin beskryf dié werkplek soos volg:

The pastor is in a peculiar position to have access to family members of the frail elderly, comparable to that of knowledgeable health care professionals.

(Gerkin 1997:223)

Wat bejaardesorg betref, sal pastors vir die individuele begeleiding van, en berading aan, ouer persone verantwoordelik wees, sowel as vir die toerusting van gemeentelede sodat hulle 'n sorgnetwerk van ondersteuning vir ouer persone kan wees. Verder is ondersteuning vir ouer persone se familie en vriende van ewe groot belang vir die pastor. Gerkin voeg boonop ondersteuning vir versorgers by wanneer hy sê:

... likewise the members of congregations to which care givers belong, are in good positions to offer support and encouragement.

(Gerkin 1997:223)

Hierdie voorstel van Gerkin is sinvol - versorgers het immers self ook ondersteuningsbehoeftes om hulle dikwels moeilike taak doeltreffend te verrig. Oor die mate waarin sodanige ondersteuning tot dusver in die Nederduitse Gereformeerde Kerk gerealiseer het, spreek Van Aarde (1999:235) hom soos volg uit: 'Ongelukkig is hierdie taakmag nie in die verlede ten volle in die kerk gebruik nie, en is daar groot uitdagings om die bydraes in die toekoms ten volle binne die kerklike strukture te gebruik.

Die versorging van ouer persone stel ' $\mathrm{n}$ besondere groot uitdaging aan die kerk. Van Aarde beskryf die dilemma ten opsigte van bejaardesorg soos volg:

Die ouer persone is aan die een kant ' $n$ eiesoortige groep met eiesoortige behoeftes. Aan die ander kant is die fout dikwels in die verlede gemaak dat die ouer persone deur die kerk net as lid van die groep bedien is en nie as individue raakgesien is nie.

(Van Aarde 1999:234)

Volgens Smuts (1989:203) behoort ouer persone nie as 'n afsonderlike groep uitgesonder te word nie, maar as deel van die gemeente hanteer te word. Vir Christengelowiges is die Bybel die brondokument vir hulle geloof, lewe en verhouding met ander. Vir geloofsgemeenskappe is die wisselwerking tussen Bybelse sienings van bejaardheid en hedendaagse sienings belangrik wat die praktyk van bejaardesorg betref. Volgens Coetzer word:

daar dikwels gevra ... of die Bybel en geskrifte van die vroë kerk oorwegend positief of negatief in hulle beskouing van die bejaarde was. Het die gemeentes destyds ouer persone op ' $n$ positiewe wyse in hulle werkswyse geintegreer, of was hulle deurgaans negatief gestereotipeer?

(Coetzer 1993:11)

Vervolgens skenk hierdie navorsing aandag aan die probleme ten opsigte van bejaardesorg in die geloofsgemeenskap van bepaald die Nederduitse Gereformeerde Kerk. Die hedendaagse situasie sal met Bybelse insigte vergelyk word. Met behulp van veral die studie van Wilhelm Coetzer (1993) van die Nederduitsch Hervormde Kerk sal die moontlikhede van doeltreffende pastorale bejaardesorg deur die pastor en geloofsgemeenskap ondersoek word.

\section{Uitdagings vir die pastorale praktyk}

Die pastorale praktyk in die Nederduitse Gereformeerde Kerk kan nie van die heersende sienings ten opsigte van ouer persone in sowel staatsbeleid as in die algemene houdings van die gemeenskap geskei word nie. In 'n diakoniologiese studie van die Nederduitse Gereformeerde Kerk word die begrip 'bejaardheid' byvoorbeeld soos volg verduidelik:

Populêr word aan ' $n$ bejaarde gedink in terme van die aftreeouderdom van 65 jaar. Hierdie ouderdomsgrens het egter geen wetenskaplike gronde nie - altans nie in die geestes- of mediese wetenskappe nie. Dit het 'n pragmatiese, sosiaal-politiesekonomiese oorsprong uit die tagtigerjare van die vorige eeu

(Nederduitse Gereformeerde Kerk 1990:199)

Reeds met die Wet op Ouderdomspensioen, Wet 22 van 1928 (wat vervang is deur Wet 38 van 1962), het die regering vir ouderdomspensioene verantwoordelikheid aanvaar. In hierdie verband word daar tans steeds tussen die geslagte onderskeid getref. Mans word op 65 as 'bejaard' beskou, en vroue op 60 .

Hierdie onderskeid is waarskynlik ook 'n praktiese aangeleentheid, omdat mans gewoonlik ' $n$ paar jaar ouer as hulle vroue is, en vroue in die verlede, by gebrek aan ' $n$ eie 
beroep, van hulle mans afhanklik was. Nieuwoudt (Nederduitse Gereformeerde Kerk 1990:199) reken dat bejaardheid wél met lewensjare verband hou, maar omdat dit van individu tot individu verskil, kan daar geen vaste grense gestel word nie.

Die aftree-ouderdom volgens die riglyne van die regering se pensioenfonds, die GEPF (Government Employees Pension Fund) is soos volg:

As from the age of 60, you may retire, unless your employment contract or law governing your employment stipulates otherwise.

(GEPF 2003:11)

Verskeie lande is volgens Labuschagne, Bekker en Van Eck (2004:40) besig om die aftree-ouderdom te verhoog ten einde die dienste van ouer persone langer te benut. Volgens die Konstitusionele Hof is die ongelyke behandeling van mense soos die onderskeid tussen aftree-ouderdom by mans en vroue, onaanvaarbaar. Labuschagne et al. (2004:44) voer verskeie redes vir hierdie diskriminasie aan. Een daarvan is dat ouderdomsdiskriminasie nie juis as 'n werklike probleem beskou word nie, ten spyte daarvan dat ouer persone te midde van samelewingsvooruitgang steeds in 'n negatiewe lig beskou word:

Although life expectancy and quality of life have in the meantime increased dramatically, the negative attitude persists.

(Labuschagne et al. 2004)

Labuschagne en kollegas betoog gevolglik dat die verskil in aftree-ouderdom by mans en vroue ongewens is, want eerder as om ouderdom as maatstaf te gebruik, moet die persoon se werksvermoë beoordeel word (Labuschagne et al. 2004:46). Die navorser stem in hierdie verband saam: Bejaardheid word nié deur lewensjare bepaal nie.

Gedurende 1982 was die Suid-Afrikaanse owerheid (Suid-Afrika 1988:2) van mening dat ouer persone as 'n nasionale bate beskou moet word. Dít het egter verander, en ná 1999, sê Nieuwoudt (Nederduitse Gereformeerde Kerk 1990), is mense se waarde eerder aan die hand van prestasie en produksievermoë bepaal, en het staatsbeleid duidelik meer op die jeug begin konsentreer. Hierdie nuwe aanslag kan ook in die Nederduitse Gereformeerde Kerk waargeneem word. Die jeug word as die volk en kerk van die toekoms gesien, terwyl ouer persone al hoe meer hulle regmatige plek verloor. Die algemene wanopvatting ten opsigte van ouer persone is dat hulle 'hulle kans gehad het', en dat hulle rol nou uitgedien is (Smuts 1989:205). Voorts word ouer persone verkeerdelik as ' $n$ homogene, uitgediende, afgetrede groep bestempel, waarin die individuele mens verlore geraak het en geen bydrae meer lewer nie (Diakoniologiese Verslag 1990). Hierteenoor is die beleidstandpunt van die Nederduitse Gereformeerde Kerk (Acta Algemene Sinode 1986:669) dat ouer persone ' $n$ integrerende deel van enige gemeente uitmaak. Meer as tien jaar later het die probleme wat in die tagtigerjare van die vorige eeu uitgewys is egter nog nie noemenswaardig verander nie, beweer Van Aarde (1999:234)

Die diakoniologiese studie (Nederduitse Gereformeerde Kerk 1990:208) toon voorts dat ouer persone materiële, psigososiale en kerklik-godsdienstige behoeftes het. Die verslag stel omvattende gesondheidsprogramme voor, en beskryf die dinge wat vir ouer persone ' $n$ sinvolle lewenservaring sal kan verskaf. Ekonomiese sekuriteit word beklemtoon, veral ten opsigte van verblyfbehoeftes. Die rol van die pastor is nie net om troos en ondersteuning aan ouer persone te bied nie, maar ook om teologiese en etiese leiding ten opsigte van hulle vrae en kwessies te gee. Die diepgaande probleme van ouer persone in die verpleeg- sowel as die sosiale en maatskaplike konteks, naamlik vereensaming, die verlies aan 'n betekenisvolle rol, sowel as die verlies aan eiewaarde, word uit 'n teologiese en geloofsperspektief deur die pastor benader. In bejaardes se lewensfase is hierdie perspektief onontbeerlik. Smuts (1989:212) toon aan dat ál bogenoemde faktore hoë eise aan die kerk strukture en lidmate stel. In hierdie verband ondersteun Van Aarde (1999:240) die Algemene Sinode van 1994 se dringende oproep dat die kerk se verantwoordelikheid ten opsigte van ouer persone moet aandag kry, en dat die kerk vroegtydig hiervoor moet beplan.

Ouer persone het geestelike ondersteuning van die kerk nodig, en het op hulle gevorderde leeftyd dikwels ' $n$ besondere behoefte aan die bediening van die evangelie. Hoewel die verpleegberoep op holistiese versorging gemik is, is dit baie gevra om ook nog geestelike en psigiese begeleiding van verpleegpersoneel te verwag. Hier kan die pastors 'n kernrol speel. Pastors en geloofsgemeenskappe kan 'n groter bydrae lewer as wat tans die geval is. Holistiese versorging sal daarby baat as hulle dus in 'n groter mate by die multidissiplinêre span betrokke raak. Die algemene beleid van die destydse Presidentsraad (Suid-Afrika 1988:93) beklemtoon dat alles in die werk gestel moet word om die bejaarde so lank moontlik selfstandig en geïntegreerd dee van die gemeenskap te hou. Dit is verblydend dat dié behoeftes al jare gelede bepaal is, en ook meer onlangs deur kerkleiers en die Kerklike Maatskaplike Diensteraad (2007) ondersteun word, soos uit hulle kommentaar op die Wet op Ouer Persone, Wet 13 van 2006, blyk.

In hulle kommentaar meld die Kerklike Maatskaplike Diensteraad (KMD) dat hulle verskillende prosesse gevolg het om ' $n$ beleid en wetgewing ten opsigte van ouer persone tot stand te bring, en is daar volgens hulle geen bepaling in die Wet op Ouer Persone wat in stryd met die Bybel is nie. Die KMD verklaar hulle steun aan die doel van die Wet (artikel 2), veral ten opsigte van die wysheid, erkenning en beskerming daarvan om deel van die leefwyse in die koninkryk van God te wees. Hulle lewer voorts die volgende kommentaar: Hoofstuk 1 in die Wet is volgens die KMD 'n goeie instrument om 'n kultuur van respek, eerbied en omgee vir ouer persone te skep. Hoofstuk 2 , wat ' $n$ bemagtigende omgewing vir dienslewering aan ouer persone bied, maak vir doeltreffende bejaardesorg voorsiening. Oor hoofstuk 3 is daar ook eenstemmigheid met betrekking tot die ontwikkeling van 'n gemeenskapsgebaseerde diens.

Hoofstuk 5 lê voorskrifte ten opsigte van residensiële versorging neer, wat die KMD al dikwels in voorafbesprekings beklemtoon het. Die KMD het wel sekere probleemgebiede uitgewys, maar het merendeels die aanbevelings van die Wet vir die pad vorentoe verwelkom (Kerklike Maatskaplike Diensteraad 2007). Uit die onderskeie liggame se voorstelle na aanleiding van die Wet op Ouer Persone, Wet 13 van 2006, blyk dit duidelik hoe belangrik ' $n$ vlot en volledige aanpassing in die samelewing vir die ouer persoon is.

Pastorale versorging van ouer persone kan nie net oor praktiese aangeleenthede, soos ekonomiese probleme, verblyf en fisieke versorging, gaan nie. Al die rolspelers uit die verskillende wetenskappe wat by bejaardesorg betrokke is, verkies 'n holistiese benadering tot bejaardesorg, aangesien mense nie in verskillende onderafdelings verdeel behoort te word nie, maar eerder as ' $n$ komplekse en eiesoortige geheel beskou moet word. Die holistiese benadering geld veral ook die pastorale versorging van ouer persone. In die pastorale sorg is die geestelike sy van menswees, wat by bejaardesorg op ander vakgebiede noodwendig minder aandag kry, van besondere belang.

Die pastor het ' $n$ verantwoordelikheid om die negatiewe emosies van angs, depressie en kommer wat by die ouer persoon bestaan uit die weg te ruim. Hierdie gevoelens kan slegs uitgeskakel word as ouer persone nie as ' $\mathrm{n}$ afsonderlike groep beskou word nie. Die rol wat die pastor ten opsigte van die fisieke, psigiese en geestelike vervul, is van groot waarde om ouer persone positief te laat verouder. Gerkin stel dit soos volg:

... they are the people who not only demonstrate their ability to cope with the exigencies of aging but use the period of life cycle to overcome lifelong disabilities and share themselves with others in unusual and creative ways

(Gerkin 1997)

Die bydrae van die pastor as mederolspeler in die ondersteuning van ouer persone om die sin van die lewe sowel as lyding te 
begryp en te verwerk, is noodsaaklik. Volgens Frankl (1997:9698) beteken ' $n$ sinvolle lewe om jou roeping te vervul, aan lewenseise te voldoen, en om die uitdaging van lewenstake te aanvaar. Voorts bring lyding ouer persone voor die uitdaging te staan om te besluit hoe hulle gaan reageer, en met watter ingesteldheid hulle hulle omstandighede gaan verwerk. Godwin beskryf die laaste fase van die verouderingsproses soos volg:

.. writing the retirement chapter of life and making it the best of all chapters calls for wisdom, commitment, perspective, energy, endurance, and undying faith in the Author and Finisher of our faith.

(Godwin 2000:240)

Met die nodige multidissiplinêre ondersteuning vir ouer persone, hóéf hulle 'laaste hoofstuk' nie 'n eensame antiklimaks te wees nie, maar eerder 'n hoogtepunt en triomf.

\section{LITERATUURVERWYSINGS}

Acta Algemene Sinode, 1986, Verslag van Barmhartigheid, NG Kerk.

Atchley, R.C., 1989, 'A continuity theory of normal aging', Gerontologist 29(2), 183-190.

Baltes, P.B., 1997, Social focus of aging, Wadsworth, Belmont.

Claassen, J.W., 2001, Gemeenskapsgebaseerde versorging: Maatskaplike perspektief, MA-verhandeling, Universiteit van Pretoria.

Coetzer, W.J., 1993, 'Bedieningstrukture van 'n bejaardebediening', PhD-proefskrif, Universiteit van Suid-Afrika.

Coetzer, W.J., 2008, Hernuwingstegnieke vir 'n sinvolle bediening aan die bejaarde, Lesing aan Teologie-studente, Hervormde Teologiese Kollege, Universiteit van Pretoria.

Cumming, E. \& Henry, W., 1961, Growing old, Basic Books, New York

Departement Welsyn, 1997, White Paper for Social Welfare, Staatsdrukkers, Pretoria.

Departement Welsyn, 1999, Financing Policy: Developmental Social Welfare Services, Staatsdrukkers, Pretoria.

Frankl, V., 1997, The search for meaning, Insight Press, New York.

Gerkin, C.V., 1997, Introduction to pastoral care, Abingdon, Nashville.

Giddens, A., 1993, Sociology, 2de uitgawe, Polity Press, Cambridge.

Godwin, J., 2000, How to retire without retreating, Barbour Publishing Inc, Uhrichsville.

GEPF, 2003, Government Employees Pension Law Amendment Bill, Government Gazette No 26676, Government Communication \& Information System Library, besigtig 10 September 2004.

Hill, D.R., 2005, Positive aging: A guide for mental health professionals and consumers, WN Norton, New York.
Hoffman, J.R., 1988, 'Sosio-gerontologie en praktiese teologie: 'n Oriëntering tot die Nederduitse Gereformeerde Kerk se georganiseerde bejaardesorg', BD-skripsie, Departement Praktiese Teologie, Universiteit van Pretoria.

Johnson, G., 2000, A user's guide to sociological language, Blackwell Malden.

Kastenbaum, R., 1993, Habituation: A key to lifespan, development and aging, Oryx Press, Phoenix.

Kerklike Maatskaplike Diensteraad, 2007, Kommentaar op Ouer Persone Wet No 13 van 2006, NG Kerk Argief, Pretoria.

Labuschagne, J.M.T., Bekker, J.C. \& Van Eck, B.P.S., 2004, 'Compulsory retirement and discrimination on the ground of old age', South African Law Journal 37:44-46.

Le Roux, M.M., 1995, Nuwe Woordeboek vir Maatskaplike Werk, CTP Book Printers, Parow.

Neugarten, B.L., Havighurst, R.J \& Tobin, S.S., 1961, 'The measurement of life satisfaction', Journal of Gerontology 16, 134-143.

Neugarten, B., Moore, J. \& Lowe, J., 1965, 'Age norms, age constraints, and adult socialization', American Journal of Sociology 70, 710-717.

Nederduitse Gereformeerde Kerk, 1990, Die diens van Barmhartigheid en Nederduitse Gereformeerde Kerk (' $n$ Diakoniologiese studie, 1990), NG Kerk Uitgewers, Noordelike Sinode, Kaapstad.

Ray, R.O. \& Heppe, G., 1986, 'Older adult happiness: The contributions of activity breadth and intensity', Physical $\mathcal{E}$ Occupational Therapy in Geriatrics 4(4), 31-44.

Riley, M.W., Hess, B.B. \& Bond, K. (reds.), 1983, Aging in society: Selected reviews of recent research, Erlbaum Associates, Hillsdale.

Rosow, I., 1974, Socialization to old age, University of California Press, Berkeley.

Smuts, A.J., 1989, Predikant en pastorale praktyk, Akademie, Johannesburg.

Suid-Afrika, 1988, 'Presidentsraadsverslag van die komitee vir maatskaplike aangeleenthede oor aspekte van veroudering', Staatsdrukkers, Pretoria.

Suid-Afrika, 2006, Older Persons Act, Staatsdrukkers, Pretoria.

Theron, D., 2006, 'Church perspective on ageing', referaat aangebied by Expo 50+ Simposium.

Van Aarde, R.B., 1999, 'Die barmhartigheidsbediening van die Nederduitse Gereformeerde Kerk van Natal: 'n Kerkhistoriese perspektief', DD-proefskrif, Universiteit van Pretoria.

Zastrow, C., 2004, Introduction to social work and social welfare: Empowering people, 8ste uitgawe, Brooks/Cole-Thomson Learning, Belmont. 